Bangladesh J. Bot. 49(1): 141-146, 2020 (March)

\title{
EFFECTS OF VERMICOMPOST AND PK ON GROWTH AND PROTEIN CONTENT OF SPINACH (SPINACIA OLERACIA L.)
}

\author{
Md Mahfuz Islam*, Sayada Momotaz Akther, Shahin Ahmed Sujon, \\ Md Abdul Karim ${ }^{1}$ and Md Khalilur Rahman \\ Department of Soil, Water and Environment, University of Dhaka,
Dhaka-1000, Bangladesh
}

Keywords: Growth, Protein, Spinach, Vermicompost

\begin{abstract}
Results of a pot experiment carried out on spinach with vermicompost (5, 10 and 15 ton/ha), phosphorous $(10,20$ and $30 \mathrm{~kg} / \mathrm{ha})$ and potassium $(20,30$ and $40 \mathrm{~kg} / \mathrm{ha})$ fertilizers showed that plant height, leaf area, fresh and dry weight of plants increased significantly $(\mathrm{p} \leq 0.5)$ over the control. Highest height $(23.55 \mathrm{~cm})$, leaf area $\left(80.88 \mathrm{~cm}^{2} /\right.$ plant $)$, fresh weight $(3.838 \mathrm{~g} / \mathrm{plant})$ and dry weight $(0.274 \mathrm{~g} /$ plant $)$ were maximum in $\mathrm{VC}_{15} \mathrm{P}_{20} \mathrm{~K}_{30}, \mathrm{VC}_{15} \mathrm{P}_{30} \mathrm{~K}_{30}, \mathrm{VC}_{10} \mathrm{P}_{20} \mathrm{~K}_{30}$ and $\mathrm{VC}_{10} \mathrm{P}_{10} \mathrm{~K}_{40}$, respectively, while leaf number was almost same in all the plants. Highest protein content $(24.61 \%)$ was obtained in the treatment $\mathrm{VC}_{15} \mathrm{P}_{10} \mathrm{~K}_{20}$. Highest dry matter of leaf was obtained at $\mathrm{VC}_{10} \mathrm{P}_{10} \mathrm{~K}_{40}$, but the highest protein content was at $\mathrm{VC}_{15} \mathrm{P}_{10} \mathrm{~K}_{20}$ which might be due to dilution effect. Similar values of protein content were obtained in treatments $\mathrm{VC}_{5} \mathrm{P}_{20} \mathrm{~K}_{30}, \mathrm{VC}_{5} \mathrm{P}_{20} \mathrm{~K}_{40}$, $\mathrm{VC}_{5} \mathrm{P}_{30} \mathrm{~K}_{20}, \mathrm{VC}_{15} \mathrm{P}_{10} \mathrm{~K}_{40}, \mathrm{VC}_{15} \mathrm{P}_{20} \mathrm{~K}_{30}$ and $\mathrm{VC}_{15} \mathrm{P}_{30} \mathrm{~K}_{20}$. Maximum value of nitrogen, phosphorous (1.621\%) and potassium (4.066\%) were obtained in treatments $\mathrm{VC}_{5} \mathrm{P}_{20} \mathrm{~K}_{20}$ and $\mathrm{VC}_{10} \mathrm{P}_{30} \mathrm{~K}_{40}, \mathrm{VC}_{15} \mathrm{P}_{10} \mathrm{~K}_{20}$, respectively.
\end{abstract}

\section{Introduction}

Spinach is believed to have originated in Persia, which later spread almost across the world and became a desirably leafy green known for good health; a reputation that stands firm still today. Spinach is an increasingly popular commercial vegetable crop in Bangladesh. Baby leaf vegetables such as rockets, lamb's lettuce and spinach are the subjects of increased consumption and are mostly recommended for mixed salad both as fresh market products and ready-to use vegetables. It is known to contain comparatively higher amounts of bioactive compounds (Gil et al. 1999), nutrient such as minerals, carbohydrates, vitamin A and C, riboflavin, nicotinic acid, thiamine (MacGillivray 1953) as well as folate, manganese, iron magnesium, potassium and calcium (USDA 2005).

The use of vermicompost to increase crop yield and soil quality has gained considerable momentum due to its contribution in agro-ecological sustainability (Xu and Mou 2016). Vermicompost has been shown to have significant beneficial effects on both soil and crop yield. It enhances soil quality by increasing microorganisms, soil aeration and by improving nutrient cycling and water (Srivastava et al. 2011, D'Hose et al. 2014) and thereby growth of spinach (Xu and Mou 2016). A very little information is available on the growth, nitrogen accumulation and protein content in spinach under Bangladesh edaphic conditions. The objective of this experiment was to study the effects of vermicompost, phosphorus and potassium on growth and protein content in spinach.

*Author for correspondence: <mdmahfuz789@ gmail.com>. ${ }^{1}$ Department of Botany, University of Dhaka, Dhaka 1000, Bangladesh. 


\section{Materials and Methods}

Soil sample (0 to $15 \mathrm{~cm}$ depth) was collected from Keraniganj, Dhaka. The sample was air dried, ground and sieved through $2 \mathrm{~mm}$ sieve. The soil had a $\mathrm{pH} 6.89$, organic matter $0.41 \%$ (Walkley and Black 1934), available N $23 \mathrm{mg} / \mathrm{kg}$ (Marr and Cresser 1983), available P $6.5 \mathrm{mg} / \mathrm{kg}$ (Murphy and Riley 1962), available K $30.8 \mathrm{mg} / \mathrm{kg}$, field capacity 30\% (Anderson and Ingram 1989), sand $12.18 \%$, silt $69.34 \%$ and clay $18.48 \%$, textural class- silt loam (Bouyoucos 1962). The $\mathrm{N}, \mathrm{P}$ and $\mathrm{K}$ concentration of vermicompost were $1.1,0.29$ and 0.82 per cent, respectively. A pot experiment was carried out in the net house of the Department of Soil, Water and Environment, University of Dhaka. Seven kilograms of soil was taken per plastic pot $(22 \mathrm{~cm} \times 24.5 \mathrm{~cm})$. Vermicompost (5, 10 and 15 ton/ha), phosphorus (10, 20 and $30 \mathrm{~kg} / \mathrm{ha}$ ) as TSP and potassium (20, 30 and $40 \mathrm{~kg} / \mathrm{ha}$ ) as MP were applied. Twenty eight treatments with three replications were completely randomized block design. Seeds of Spinacia oleracia were collected from local market, Dhaka. Fifteen seeds were sown and finally eight plants were kept per pot. Height, number of leaves and leaf area of the plants were measured.

Table 1. Treatment combinations.

\begin{tabular}{cccc}
\hline Treatments & $\begin{array}{c}\text { Treatment combination } \\
\text { (VC ton/ha and } \mathrm{PK} \text { kg/ha) }\end{array}$ & Treatments & $\begin{array}{c}\text { Treatment combination } \\
\text { (VC ton/ha and } \mathrm{PK} \text { kg/ha) }\end{array}$ \\
\hline $\mathrm{T}_{1}$ & $\mathrm{VC}_{0} \mathrm{P}_{0} \mathrm{~K}_{0}$ & $\mathrm{~T}_{15}$ & $\mathrm{VC}_{10} \mathrm{P}_{20} \mathrm{~K}_{30}$ \\
$\mathrm{~T}_{2}$ & $\mathrm{VC}_{5} \mathrm{P}_{10} \mathrm{~K}_{20}$ & $\mathrm{~T}_{16}$ & $\mathrm{VC}_{10} \mathrm{P}_{20} \mathrm{~K}_{40}$ \\
$\mathrm{~T}_{3}$ & $\mathrm{VC}_{5} \mathrm{P}_{10} \mathrm{~K}_{30}$ & $\mathrm{~T}_{17}$ & $\mathrm{VC}_{10} \mathrm{P}_{30} \mathrm{~K}_{20}$ \\
$\mathrm{~T}_{4}$ & $\mathrm{VC}_{5} \mathrm{P}_{10} \mathrm{~K}_{40}$ & $\mathrm{~T}_{18}$ & $\mathrm{VC}_{10} \mathrm{P}_{30} \mathrm{~K}_{30}$ \\
$\mathrm{~T}_{5}$ & $\mathrm{VC}_{5} \mathrm{P}_{20} \mathrm{~K}_{20}$ & $\mathrm{~T}_{19}$ & $\mathrm{VC}_{10} \mathrm{P}_{30} \mathrm{~K}_{40}$ \\
$\mathrm{~T}_{6}$ & $\mathrm{VC}_{5} \mathrm{P}_{20} \mathrm{~K}_{30}$ & $\mathrm{~T}_{20}$ & $\mathrm{VC}_{15} \mathrm{P}_{10} \mathrm{~K}_{20}$ \\
$\mathrm{~T}_{7}$ & $\mathrm{VC}_{5} \mathrm{P}_{20} \mathrm{~K}_{40}$ & $\mathrm{~T}_{21}$ & $\mathrm{VC}_{15} \mathrm{P}_{10} \mathrm{~K}_{30}$ \\
$\mathrm{~T}_{8}$ & $\mathrm{VC}_{5} \mathrm{P}_{30} \mathrm{~K}_{20}$ & $\mathrm{~T}_{22}$ & $\mathrm{VC}_{15} \mathrm{P}_{10} \mathrm{~K}_{40}$ \\
$\mathrm{~T}_{9}$ & $\mathrm{VC}_{5} \mathrm{P}_{30} \mathrm{~K}_{30}$ & $\mathrm{~T}_{23}$ & $\mathrm{VC}_{15} \mathrm{P}_{20} \mathrm{~K}_{20}$ \\
$\mathrm{~T}_{10}$ & $\mathrm{VC}_{5} \mathrm{P}_{30} \mathrm{~K}_{40}$ & $\mathrm{~T}_{24}$ & $\mathrm{VC}_{15} \mathrm{P}_{20} \mathrm{~K}_{30}$ \\
$\mathrm{~T}_{11}$ & $\mathrm{VC}_{10} \mathrm{P}_{10} \mathrm{~K}_{20}$ & $\mathrm{~T}_{25}$ & $\mathrm{VC}_{15} \mathrm{P}_{20} \mathrm{~K}_{40}$ \\
$\mathrm{~T}_{12}$ & $\mathrm{VC}_{10} \mathrm{P}_{10} \mathrm{~K}_{30}$ & $\mathrm{~T}_{26}$ & $\mathrm{VC}_{15} \mathrm{P}_{30} \mathrm{~K}_{20}$ \\
$\mathrm{~T}_{13}$ & $\mathrm{VC}_{10} \mathrm{P}_{10} \mathrm{~K}_{40}$ & $\mathrm{~T}_{27}$ & $\mathrm{VC}_{15} \mathrm{P}_{30} \mathrm{~K}_{30}$ \\
$\mathrm{~T}_{14}$ & $\mathrm{VC}_{10} \mathrm{P}_{20} \mathrm{~K}_{20}$ & $\mathrm{~T}_{28}$ & $\mathrm{VC}_{15} \mathrm{P}_{30} \mathrm{~K}_{40}$ \\
\hline
\end{tabular}

Fifty days old plants were harvested as leaf, stem, root and washed with tap water and finally with distilled water and wrapped with soft tissue paper. Immediately after harvest, fresh weight of leaf, stem and root were taken and then air-dried in the room temperature and finally oven-dried at $65^{\circ} \mathrm{C}$ in an oven for $72 \mathrm{hrs}$. Dry weight of the sample was recorded, ground with a mechanical grinder and stored. For nitrogen, $0.2 \mathrm{~g}$ of powdered sample was digested in a Kjeldahl digestion flask (Jackson 1962) and for PK, $0.5 \mathrm{~g}$ powdered leaf was digested (Shelton and Harper 1941). Phosphorous of the digest was determined by vanadomolybdophosphoric yellow color method at $430 \mathrm{~nm}$ using spectrophotometer (Model DR 5000). Potassium in the digest was determined by using JENWAY flame photometer (Model PFP 7). Protein content of the leaf was determined by the methods of Magomya et al. (2014). 
Statistical analysis of the results was carried out using Microsoft Excel 2010 and respective LSDs are indicated. Graphs were also prepared by using the Microsoft Excel 2010.

\section{Results and Discussion}

Plant growth was assessed in terms of plant height, leaf number and leaf area (Table 2), fresh and dry weight of leaf, stem and root (Table 3). Results of height and leaf area varied significantly $(\mathrm{p} \leq 0.5)$ at harvest over the control but the values of number of leaves did not vary significantly (Table 2). However, the highest height $(23.55 \mathrm{~cm})$ was observed in pot treated with $\mathrm{VC}_{15} \mathrm{P}_{20} \mathrm{~K}_{30}$ followed by $23.5 \mathrm{~cm}$ under $\mathrm{VC}_{5} \mathrm{P}_{10} \mathrm{~K}_{30}$ treatment. Application of the highest vermicompost dose based on crop $\mathrm{N}$ requirements was likely to provide more nutrients to the crops (Edwards and Daniel 1992). Leaf number in different treatments increased up to harvest (Table 2) but did not vary significantly. Maximum leaf area $\left(80.88 \mathrm{~cm}^{2} /\right.$ plant) was achieved in $\mathrm{VC}_{15} \mathrm{P}_{30} \mathrm{~K}_{30}$ treatment followed by $77.55 \mathrm{~cm}$ in $\mathrm{VC}_{15} \mathrm{P}_{20} \mathrm{~K}_{30}$. The values for fresh weights of leaf, stem, root and dry weight of leaf and stem as well as total fresh and dry weight varied significantly $(p \leq 0.5)$ (Table 3). The maximum total yields of fresh and dry weights were 3.8376 and $0.2744 \mathrm{~g} / \mathrm{plant}$ recorded in $\mathrm{VC}_{10} \mathrm{P}_{20} \mathrm{~K}_{30}$ and $\mathrm{VC}_{10} \mathrm{P}_{10} \mathrm{~K}_{40}$ treatments, respectively (Table 3). Nitrogen is the most imperative element for proper growth and development of plants which significantly increases the yield and
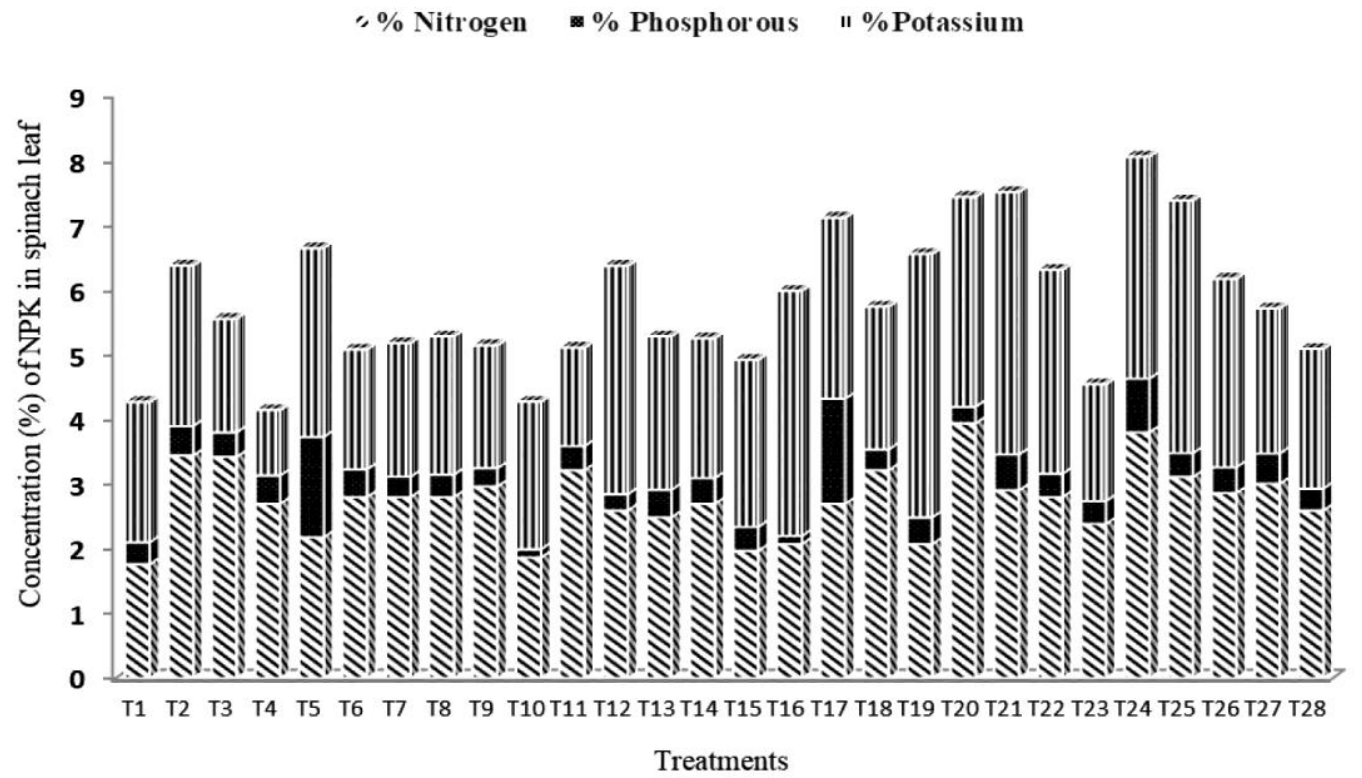

Fig. 1. Effects of vermicompost and PK on the concentration (\%) of N, P and $\mathrm{K}$ in the leaf of spinach.

its quality by playing vital role in biochemical and physiological functions of plant (Leghari et al. 2016). Brady and Weil (2002) concluded that the organic manures contain a passive fraction of 60 to 90 per cent which is very slowly available to plants. Akon et al. (2018) found that height, leaf area, and fresh and dry weights of leaf of Gynura procumbens varied significantly $(\mathrm{p} \leq 0.5)$ under seven types of manures including vermicompost. 
Table 2. Effects of vermicompost and PK on height, leaf numbers and leaf area of spinach (Spinacia oleracea) after 50 days of growth.

\begin{tabular}{|c|c|c|c|}
\hline $\begin{array}{c}\text { Treatments } \\
(\mathrm{VC} \text { ton/ha and } \mathrm{PK} \mathrm{kg} / \mathrm{ha})\end{array}$ & $\begin{array}{l}\text { Height } \\
(\mathrm{cm})\end{array}$ & $\begin{array}{l}\text { Leaf number } \\
\text { (no./plant) }\end{array}$ & $\begin{array}{l}\text { Leaf area } \\
\left(\mathrm{cm}^{2} / \text { plant }\right)\end{array}$ \\
\hline $\mathrm{VC}_{0} \mathrm{P}_{0} \mathrm{~K}_{0}$ & 16.50 & 8 & 34.80 \\
\hline $\mathrm{VC}_{5} \mathrm{P}_{10} \mathrm{~K}_{20}$ & 19.30 & 8 & 51.85 \\
\hline $\mathrm{VC}_{5} \mathrm{P}_{10} \mathrm{~K}_{30}$ & 23.50 & 9 & 59.58 \\
\hline $\mathrm{VC}_{5} \mathrm{P}_{10} \mathrm{~K}_{40}$ & 21.20 & 9 & 75.70 \\
\hline $\mathrm{VC}_{5} \mathrm{P}_{20} \mathrm{~K}_{20}$ & 20.10 & 9 & 46.58 \\
\hline $\mathrm{VC}_{5} \mathrm{P}_{20} \mathrm{~K}_{30}$ & 18.60 & 9 & 53.25 \\
\hline $\mathrm{VC}_{5} \mathrm{P}_{20} \mathrm{~K}_{40}$ & 19.75 & 9 & 39.54 \\
\hline $\mathrm{VC}_{5} \mathrm{P}_{30} \mathrm{~K}_{20}$ & 21.05 & 9 & 59.30 \\
\hline $\mathrm{VC}_{5} \mathrm{P}_{30} \mathrm{~K}_{30}$ & 19.00 & 9 & 54.09 \\
\hline $\mathrm{VC}_{5} \mathrm{P}_{30} \mathrm{~K}_{40}$ & 19.50 & 9 & 40.06 \\
\hline $\mathrm{VC}_{10} \mathrm{P}_{10} \mathrm{~K}_{20}$ & 21.50 & 9 & 69.06 \\
\hline $\mathrm{VC}_{10} \mathrm{P}_{10} \mathrm{~K}_{30}$ & 19.10 & 9 & 53.39 \\
\hline $\mathrm{VC}_{10} \mathrm{P}_{10} \mathrm{~K}_{40}$ & 21.45 & 9 & 70.04 \\
\hline $\mathrm{VC}_{10} \mathrm{P}_{20} \mathrm{~K}_{20}$ & 20.90 & 9 & 66.58 \\
\hline $\mathrm{VC}_{10} \mathrm{P}_{20} \mathrm{~K}_{30}$ & 20.75 & 9 & 70.15 \\
\hline $\mathrm{VC}_{10} \mathrm{P}_{20} \mathrm{~K}_{40}$ & 21.25 & 8 & 49.54 \\
\hline $\mathrm{VC}_{10} \mathrm{P}_{30} \mathrm{~K}_{20}$ & 18.10 & 9 & 46.80 \\
\hline $\mathrm{VC}_{10} \mathrm{P}_{30} \mathrm{~K}_{30}$ & 19.85 & 9 & 49.56 \\
\hline $\mathrm{VC}_{10} \mathrm{P}_{30} \mathrm{~K}_{40}$ & 20.05 & 9 & 45.57 \\
\hline $\mathrm{VC}_{15} \mathrm{P}_{10} \mathrm{~K}_{20}$ & 17.90 & 8 & 42.57 \\
\hline $\mathrm{VC}_{15} \mathrm{P}_{10} \mathrm{~K}_{30}$ & 19.80 & 9 & 50.90 \\
\hline $\mathrm{VC}_{15} \mathrm{P}_{10} \mathrm{~K}_{40}$ & 19.40 & 9 & 64.65 \\
\hline $\mathrm{VC}_{15} \mathrm{P}_{20} \mathrm{~K}_{20}$ & 20.00 & 9 & 53.33 \\
\hline $\mathrm{VC}_{15} \mathrm{P}_{20} \mathrm{~K}_{30}$ & 23.55 & 9 & 77.55 \\
\hline $\mathrm{VC}_{15} \mathrm{P}_{20} \mathrm{~K}_{40}$ & 19.55 & 9 & 54.33 \\
\hline $\mathrm{VC}_{15} \mathrm{P}_{30} \mathrm{~K}_{20}$ & 18.60 & 9 & 47.01 \\
\hline $\mathrm{VC}_{15} \mathrm{P}_{30} \mathrm{~K}_{30}$ & 21.80 & 9 & 80.88 \\
\hline $\mathrm{VC}_{15} \mathrm{P}_{30} \mathrm{~K}_{40}$ & 21.00 & 9 & 58.02 \\
\hline LSD at $5 \%$ & 1.828 & NS & 7.301 \\
\hline
\end{tabular}


Table 3. Effects of vermicompost and PK on the fresh, dry weights and protein content $(\%)$ of spinach (Spinacia oleracea).

\begin{tabular}{|c|c|c|c|c|c|c|c|}
\hline \multirow{2}{*}{$\begin{array}{c}\text { Treatments } \\
\text { (VC ton/ha and } \\
\text { PK kg/ha) }\end{array}$} & \multicolumn{3}{|c|}{$\begin{array}{l}\text { Fresh weight } \\
\text { (g/plant) }\end{array}$} & \multicolumn{3}{|c|}{$\begin{array}{l}\text { Dry weight } \\
\text { (g/plant) }\end{array}$} & \multirow{2}{*}{$\begin{array}{c}\text { Protein } \\
\text { content } \\
(\%)\end{array}$} \\
\hline & Leaf & Stem & $\begin{array}{c}\text { Total (root }+ \\
\text { shoot) }\end{array}$ & Leaf & Stem & $\begin{array}{l}\text { Total (root } \\
+ \text { shoot) }\end{array}$ & \\
\hline $\mathrm{VC}_{0} \mathrm{P}_{0} \mathrm{~K}_{0}$ & 1.213 & 0.241 & 1.506 & 0.088 & 0.031 & 0.134 & 11.008 \\
\hline $\mathrm{VC}_{5} \mathrm{P}_{10} \mathrm{~K}_{20}$ & 1.580 & 0.290 & 1.933 & 0.104 & 0.038 & 0.164 & 15.497 \\
\hline $\mathrm{VC}_{5} \mathrm{P}_{10} \mathrm{~K}_{30}$ & 3.258 & 0.353 & 3.693 & 0.193 & 0.054 & 0.272 & 16.068 \\
\hline $\mathrm{VC}_{5} \mathrm{P}_{10} \mathrm{~K}_{40}$ & 2.560 & 0.279 & 2.885 & 0.111 & 0.034 & 0.156 & 15.835 \\
\hline $\mathrm{VC}_{5} \mathrm{P}_{20} \mathrm{~K}_{20}$ & 2.055 & 0.260 & 2.383 & 0.131 & 0.042 & 0.204 & 14.600 \\
\hline $\mathrm{VC}_{5} \mathrm{P}_{20} \mathrm{~K}_{30}$ & 1.976 & 0.283 & 2.303 & 0.109 & 0.068 & 0.225 & 17.483 \\
\hline $\mathrm{VC}_{5} \mathrm{P}_{20} \mathrm{~K}_{40}$ & 1.531 & 0.266 & 1.871 & 0.070 & 0.039 & 0.135 & 14.483 \\
\hline $\mathrm{VC}_{5} \mathrm{P}_{30} \mathrm{~K}_{20}$ & 2.965 & 0.215 & 3.406 & 0.122 & 0.046 & 0.192 & 18.482 \\
\hline $\mathrm{VC}_{5} \mathrm{P}_{30} \mathrm{~K}_{30}$ & 1.938 & 0.299 & 2.300 & 0.102 & 0.034 & 0.150 & 18.520 \\
\hline $\mathrm{VC}_{5} \mathrm{P}_{30} \mathrm{~K}_{40}$ & 1.580 & 0.306 & 1.929 & 0.104 & 0.026 & 0.160 & 13.655 \\
\hline $\mathrm{VC}_{10} \mathrm{P}_{10} \mathrm{~K}_{20}$ & 3.016 & 0.371 & 3.471 & 0.194 & 0.049 & 0.267 & 20.073 \\
\hline $\mathrm{VC}_{10} \mathrm{P}_{10} \mathrm{~K}_{30}$ & 1.949 & 0.296 & 2.298 & 0.116 & 0.032 & 0.157 & 16.188 \\
\hline $\mathrm{VC}_{10} \mathrm{P}_{10} \mathrm{~K}_{40}$ & 3.040 & 0.393 & 3.485 & 0.200 & 0.054 & 0.274 & 15.540 \\
\hline $\mathrm{VC}_{10} \mathrm{P}_{20} \mathrm{~K}_{20}$ & 2.410 & 0.381 & 2.855 & 0.144 & 0.071 & 0.242 & 16.935 \\
\hline $\mathrm{VC}_{10} \mathrm{P}_{20} \mathrm{~K}_{30}$ & 3.366 & 0.383 & 3.838 & 0.150 & 0.028 & 0.180 & 12.303 \\
\hline $\mathrm{VC}_{10} \mathrm{P}_{20} \mathrm{~K}_{40}$ & 2.015 & 0.184 & 2.399 & 0.101 & 0.046 & 0.185 & 14.950 \\
\hline $\mathrm{VC}_{10} \mathrm{P}_{30} \mathrm{~K}_{20}$ & 1.939 & 0.252 & 2.285 & 0.168 & 0.056 & 0.268 & 16.635 \\
\hline $\mathrm{VC}_{10} \mathrm{P}_{30} \mathrm{~K}_{30}$ & 1.506 & 0.285 & 1.813 & 0.089 & 0.045 & 0.136 & 20.700 \\
\hline $\mathrm{VC}_{10} \mathrm{P}_{30} \mathrm{~K}_{40}$ & 1.634 & 0.256 & 1.954 & 0.074 & 0.053 & 0.159 & 15.950 \\
\hline $\mathrm{VC}_{15} \mathrm{P}_{10} \mathrm{~K}_{20}$ & 1.331 & 0.269 & 1.646 & 0.083 & 0.058 & 0.154 & 24.605 \\
\hline $\mathrm{VC}_{15} \mathrm{P}_{10} \mathrm{~K}_{30}$ & 1.919 & 0.336 & 2.304 & 0.128 & 0.063 & 0.209 & 18.130 \\
\hline $\mathrm{VC}_{15} \mathrm{P}_{10} \mathrm{~K}_{40}$ & 2.868 & 0.350 & 3.261 & 0.170 & 0.047 & 0.245 & 17.483 \\
\hline $\mathrm{VC}_{15} \mathrm{P}_{20} \mathrm{~K}_{20}$ & 2.499 & 0.318 & 2.918 & 0.121 & 0.051 & 0.212 & 19.893 \\
\hline $\mathrm{VC}_{15} \mathrm{P}_{20} \mathrm{~K}_{30}$ & 3.029 & 0.288 & 3.406 & 0.187 & 0.052 & 0.255 & 23.733 \\
\hline $\mathrm{VC}_{15} \mathrm{P}_{20} \mathrm{~K}_{40}$ & 2.649 & 0.310 & 3.004 & 0.119 & 0.032 & 0.161 & 19.425 \\
\hline $\mathrm{VC}_{15} \mathrm{P}_{30} \mathrm{~K}_{20}$ & 2.216 & 0.294 & 2.589 & 0.098 & 0.046 & 0.165 & 17.871 \\
\hline $\mathrm{VC}_{15} \mathrm{P}_{30} \mathrm{~K}_{30}$ & 2.490 & 0.360 & 2.893 & 0.131 & 0.063 & 0.213 & 18.778 \\
\hline $\mathrm{VC}_{15} \mathrm{P}_{30} \mathrm{~K}_{40}$ & 2.569 & 0.391 & 3.036 & 0.160 & 0.068 & 0.240 & 16.102 \\
\hline LSD at $5 \%$ & 0.848 & 0.119 & 0.893 & 0.248 & 0.160 & 0.046 & 0.892 \\
\hline
\end{tabular}

Protein content in leaf is presented in Table 2 where maximum and minimum amount of protein was achieved in $\mathrm{VC}_{15} \mathrm{P}_{10} \mathrm{~K}_{20}$ and control treatment $\left(\mathrm{VC}_{0} \mathrm{P}_{0} \mathrm{~K}_{0}\right)$, respectively. Magomya et al. (2014) collected ten different plant samples from wild and farmland of Nizeria viz., Hibiscus cannabinus, Haematostaphis barteri, Sesamum indicum, Balanites aegyptiaca, Cassia tora, Celtis integrifolia, Anona senegalensiss, Ceiba petandra, Ficus ingens and Solanum melongena the protein of which ranged from $2.63-18.59 \%$. 


\section{References}

Akon MOS, Datta DK, Biswas T, Nakamura K and Rahman MK 2018. Influence of organic manures on the growth of diabetes preventive medicinal plant Gynura, Gynura procumbens. Journal of Biodiversity Conservation and Bioresource Management 4(2): 61-66.

Anderson JM and Ingram JSI 1989. Soil Physical Analysis: Field capacity. In: Tropical Soil Biology and Fertility: A Handbook of Methods. CAB International, Wallingford, Oxon OX10 8DE, UK. pp. 50-51.

Ashrafi S 2018. Response of cow-dung and poultry manure on growth and yield of spinach under salt stress. Unpublished MS Thesis, University of Dhaka, Dhaka -1000. pp. 91.

Bouyoucos GT 1962. Hydrometer method improved for making particle size analysis of soils. Agronomy Journal 54: 461-465.

Brady NC, and Weil RR 2002. The Nature and Properties of Soils. 13th edition, Pearson Education Pte. Ltd., Singapore. pp. 960.

D'Hose Y, Cougnon M, De Vliegher A, Vandecasteele B, Viaene N, Cornelis W, Bockstaele EV and Reheul D 2014. The positive relationship between soil quality and crop production: A case study on the effect of farm compost application. Applied Soil and Ecology 75: 189-198.

Edwards DR, and Daniel, TC 1992. Environmental impacts of on-farm poultry waste disposal: A review. Bioresource Technology 41: 9-33.

Gil MI, Ferreres F and Tomas-Barberan FA 1999. Effect of postharvest storage and processing on the antioxidant constituents (flavonoids and vitamin c) of fresh cut spinach. Journal of Agriculture, Food and Chemistry 47: 2213-2217.

Jackson ML 1962. Soil Chemical Analysis. Prentice Hall Inc. Englewood Cliffs. N. J. USA. pp. 498.

Kaiser WM 1982. Correlation between changes in photosynthetic activity and changes in total protoplast volume in leaf tissue from hygro-, meso- and xerophytes under osmotic stress. Planta 154: 538-545

Leghari SJ, Wahocho NA, Laghari GM, Bhabhan GM, Talpur KH, Bhutto TA, Wahocho SA and Lashari AA 2016. Role of nitrogen for plant growth and development: a review. Advanced Environmental Biology 10 (9): 209-218.

Magomya AM, Kubmarawa D, Ndahi JA, Yebpella GG 2014.Determination of Plant Proteins via the Kjeldahl method and amino acid analysis: A comparative study. International Journal of Scientific and Technology Research 3(4): 68-72.

MacGillivray JH 1953. Vegetable Production. Blackistan and Co. New York, USA.

Marr IL and Cresser MS 1983. The lithosphere. In: Environmental Chemical Analysis. Blackie and Son, UK, pp. 155-182.

Murphy J and Riley JP 1962. A modified single solution method for the determination of phosphate in natural waters. Analytica Chimica Acta 27: 31-36

Shelton WR and Harper HJ 1941. A rapid method for the determination of total phosphorus in soil and plant material. Iowa State College. J. Sci. 15: 403-413.

Srivastava PK, Singh PC, Gupta M, Sinha A, Vaish A, Shukla A, Singh N and Tewari SK 2011. Influence of earthworm culture on fertilization potential and biological activities of vermicomposts prepared from different plant wastes. Journal of Plant Nutrition and Soil Science 174: 420-429.

United States Department of Agriculture (USDA) 2005. U.S. Department of Agriculture, Agricultural Research Service. USDA National Nutrient Database for Standard Reference, Washington DC, Release 18.

Walkley A and Black IA 1934. An examination of the Degtjareff method for determining soil organic matter and a proposed modification of the chromic acid titration method. Soil Science 37: 29-38.

Xu C and Mou B 2016. Vermicompost affects soil properties and spinach growth, physiology, and nutritional value. Horticultural Science 51(7): 847-855.

(Manuscript received on 9 May, 2019; revised on 27 May, 2019) 